\title{
Utilization Waste Brine Water Separator for Binary Electric Energy Conversion in Geothermal Wells
}

\author{
Herianto \\ Petroleum Engineering Department, UPN Veteran Yogyakarta, Yogyakarta 55283, Indonesia
}

Corresponding Author Email: herianto_upn_ina@yahoo.com

https://doi.org/10.18280/ijdne.160408

Received: 26 October 2020

Accepted: 10 August 2021

\section{Keywords:}

binary cycle, working fluid type, brine temperature, optimization, environmentally friendly

\begin{abstract}
Nowadays, geothermal is one of the most environmentally friendly energy that can replace the role of fossils energy by converting steam to electricity. Brine is one of the by-products of the production of geothermal wells that are generally not used or simply re-injected. In fact, brine can be converted into electricity using the binary cycle process. In binary cycle, brine from separator is used as a heater of working fluid and transform it into a vapor phase. The vapor will be used to turn turbines and generators to produce electricity. The working fluid selection in accordance with the heating fluid temperature becomes important because it results in optimization of the thermodynamic cycle. The temperature of the wellhead in the geothermal field will decrease $3 \%$ per year and reducing the heating fluid temperature in heat exchanger. So, in this paper intends to utilizes brine to heat the heat exchanger by using iso-butane, n-pentane, and iso-pentane because its critical temperature can be stable at $193^{\circ} \mathrm{C}$ wellhead temperatures. From the results of predictions from brain 2 production well for 17 years with iso-butane in this binary cycle planning, can utilize waste brine water separator to converse electric energy to produce $4 \mathrm{MWh}$ electricity.
\end{abstract}

\section{INTRODUCTION}

In general, geothermal fields only use their steam by converting the steam to electricity. Brine that are produced with a high temperature, pressure, and mass flow rate can be used as electricity generation. Brine will only function as a heater of the working fluid. The working fluid used is a chemical compound that has a boiling point lower than the boiling point of water [1]. The heated working fluid vapors are later used to turn turbines and produce electricity.

Many working fluids can be used for binary cycle power plants. There have been many studies conducted to find out the most efficient working fluid applied to a power plant. Each working fluid must have basic characteristics, such as being able to produce high efficiency, as well as non-toxic, nonflammable, have low Global Warming Potential (GWP), do not have the potential to damage the ozone layer (ODP), and the cost is cheap [2]. Working fluids with high GWP such as chlorofluorocarbons (CFCs) were not included in this analysis. Refrigerants that contain chlorine or bromine can cause a decrease in the ozone layer. These components are unstable and when released into the atmosphere, they quickly go to the uppermost atmosphere [3]. Another parameter that needs to be considered is the pressure of the working fluid, whether the pressure is condensation or evaporation. Some working fluids have large evaporative pressures such as isobutane and nbutane, which means they require extensive evaporators [4].

Working fluids which have high latent heat and high density are preferred. The working fluid absorbs more energy from its source in the evaporator. This will reduce the amount of fluid mass flow rate needed. Thus, resulting in the use of smaller generating facilities and pump power consumption [5]. There are three types of working fluids based on the slope of the saturated vapor line on the T-s diagram, namely dry, wet and isotropic fluids. Dry and isotropic working fluids produce better performance than wet fluids. The effect of boiling temperature on the thermal efficiency system is also considered. High-boiling work fluids have higher thermal efficiency [6].

Some researchers do model either numerically or using software tools to predict the performance results of certain working fluids which are determined in advance from the temperature of the heating fluid in the cycle $[7,8]$. In addition, it can estimate the difference between the actual value in the field with the value when the binary cycle has been used [9]. Studies conducted with a heating fluid model from Wayang Windu wells in Indonesia, showed satisfactory results [10].

In this study, dry working fluid is used and will be analyzed in the study, namely n-pentane, and iso-pentane, and isobutane. In previous studies, research on working fluids only choose the optimum working fluid for use in a field with particular condition. However, this study will discuss the prediction of the working fluid choice on the effect of wellhead temperature decline every year. The expected result is a working fluid suitable for use in certain wellhead temperature ranges. So that it can produce optimum electricity.

This research does not develop a mathematical equation, but explains the design of the utilization that the flue fluid, which is generally directly injected into the injection well, can be used to produce a large enough electric power with a binary cycle. The amount of electric power generated depends on the mass flow rate and the temperature of the brine fluid from the separator output, which will determine the mass flow rate and working fluid temperature. The pressure and temperature of 
the working fluid will determine the amount of enthalpy of the working fluid entering the turbine. The mass flow rate of the working fluid and the enthalpy that will enter the turbine determine the amount of electric power generated $[11,12]$. In the case study, the effect of the sensitivity of the wellhead temperature drops on the type of working fluid used and the optimization of the electric power generated.

\section{FIELD STUDY AND DATA}

Binary cycle is a thermodynamic process where the main source is a hot fluid which is used to heat a working fluid through a heat exchanger [13]. The process of working fluid evaporation, usually called a closed cycle, is connected directly to the turbine as a power plant. The working principle of the binary cycle is that the brine from the production well will be flowed into one of the pipes in the heat exchanger to vaporize working fluids that have low boiling points such as iso-butane, n-pentane, and iso-pentane. Steam produced by heating the working fluid in the heat exchanger is flowed to turn the turbine and then drive the generator to produce electricity.

The working fluid selection must be done in order to produce optimum energy. Thermodynamic analysis of the working fluid is also carried out in order to know the process that occurs in the working fluid during the binary cycle. After the thermodynamic cycle is known, the next step is to design the binary cycle.

Initially, the LHD Field will only utilize the steam produced to generate Steam Turbine. However, seeing the huge potential of brine seen from pressure, temperature, and mass flow, the Unit III LHD Field has the potential to build binary cycle power plant. The planned binary cycle scheme from Produced Well LHD-5 and LHD-19, is seen in Figure 1.

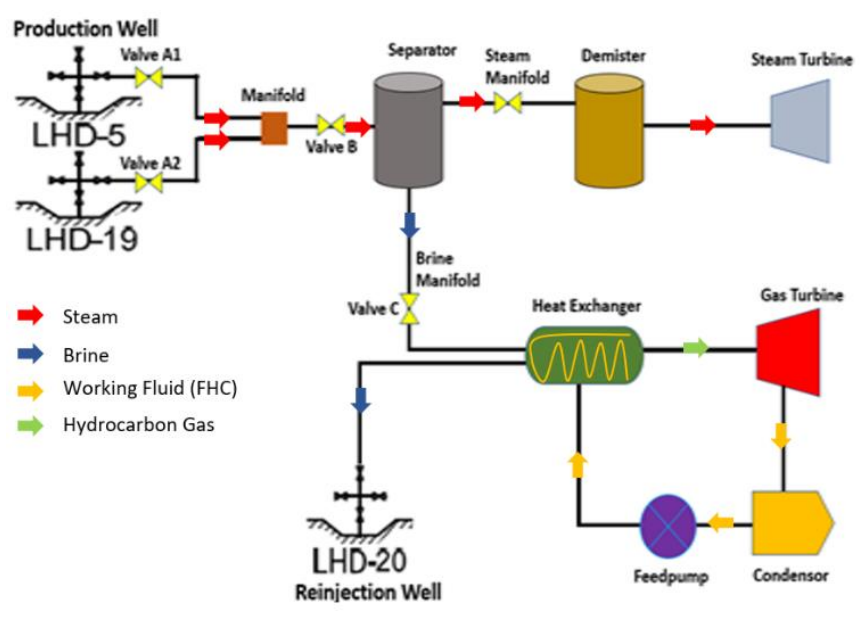

Figure 1. LHD binary cycle scheme

From Figure 1, 2-phase geothermal fluid (steam and brine) flowing from the production wells LHD-5 and LHD-19 is flowed to the manifold, respectively, with pipes measuring ID $=11.75$ in and $\mathrm{OD}=12.75$ in. Then it is flowed with one pipe measuring ID $=15$ in and OD $=16$ in to the Separator. In the separator the fluid is separated from the flashing system, where the steam will rise to the top and exit from the separator to the steam turbine. Brine from the separation from the Separator exits from the bottom of the Separator to the Heat exchanger to ensure the working fluid, after heating the working fluid, this brine fluid is flowed into the injection well to be injected into the reservoir. Hydrocarbon working fluid from the Feed pump is pumped to the Heat exchanger to be heated so that it changes its phase to gas and the Hydrocarbon gas from the Heat exchanger is flowed to the gas turbine to produce electric power $[3,5,6]$. Then the exhaust gas from the turbine is cooled in the condenser so that it returns to the liquid phase and is flowed to the feed pump as the working fluid again.

\section{METHODOLOGY}

This study is carried out in several stages:

\subsection{Pressure and temperature loss analysis and pipe dimension}

Pressure and temperature loss calculations in the two-phase pipeline are needed because there might be losses in the pipeline. Later, the use of the Pipe sim application is needed to calculate the pressure loss, temperature loss, and steam quality in the pipe. Equation from Beg and Brill to recommendation from to analysis pressure and heat loss 2 phase in pipe media.

Before calculating the amount of pressure loss and temperature loss in the two-phase pipe, it is necessary to determine the size of the pipe diameter to be used. Calculation of the dimensions of this pipe using the ASME standard. The steps in determining the dimensions of a pipe are as follows:

Determine the specific volume mixture between steam and brine using equation:

$$
V_{m}=x \times V_{v}+(1-x) \times V_{1}
$$

Determine a temporary Di (inner diameter) using equation:

$$
D i_{2}=\frac{m \times V_{m}}{\frac{1}{4} \times \pi \times V}
$$

where:

$\mathrm{V}=$ Velocity $(\mathrm{m} / \mathrm{s})$;

$\mathrm{m}=$ Flow mass $(\mathrm{kg} / \mathrm{s})$;

$\mathrm{V}_{\mathrm{m}}=$ Specific volume mixture $\left(\mathrm{m}^{3} / \mathrm{kg}\right)$;

$\mathrm{D}_{\mathrm{i}}=$ Inner diameter $(\mathrm{m})$.

Determine pipe dimension or schedule based on calculated temporary inner diameter. Calculate minimum thickness of pipe and then validate it with pipe schedule from ASME standard and calculate flow velocity inside pipe.

\subsection{Determining thermodynamic cycle of each working fluid}

Determine Thermodynamics State of Working Fluid usually consist of 6 states based on the enthalpy and entropy curves of the working fluid to changes in pressure and temperature condition The any times when state 2 has 2 values, namely $2 \mathrm{~s}$ and 2, with are differentiated because of the isotropic condition so that the status of different, so also at point $5 \mathrm{~s}$ and 5 , the same thing is found. Generally, there are four processes in the binary cycle, namely isentropic in the feed pump, 
constant pressure adding heat to the heat exchanger, turbine isotropic expansion, and heat re-injection constant pressure in the condenser.

\subsection{Calculating electrical power generated by turbine}

After knowing the thermodynamic state fluid cycle, and then calculating the mas flow rate of the working fluid using the following equation:

$$
M_{w f}=\frac{m_{b} \times C_{b} \times\left(T_{A}-T_{B}\right)}{h_{1}-h_{6}}
$$

Assuming $\Delta \mathrm{Tpp}=5^{\circ} \mathrm{K}$ (specification of the tools used), then:

$$
T_{B}=T_{6}+5 K
$$

where:

$\mathbf{M}_{\mathrm{wf}}=$ The mass flow rate of the working fluid ( $\left.\mathrm{kg} / \mathrm{s}\right)$;

$\mathrm{m}_{\mathrm{b}}=$ Brine flow rate $(\mathrm{kg} / \mathrm{s})$;

$\mathrm{T}_{\mathrm{A}}=$ Brine Temperature $\left({ }^{\circ} \mathrm{K}\right)$;

$\mathrm{T}_{\mathrm{B}}=$ Brine Temperature out $\left({ }^{\circ} \mathrm{K}\right)$;

$\mathrm{h}_{1}=$ Enthalpy of incoming working fluid $(\mathrm{kJ} / \mathrm{kg})$;

$\mathrm{h}_{2}=$ Enthalpy of the working fluid out $(\mathrm{kJ} / \mathrm{kg})$;

$\mathrm{T}_{6}=$ Temperature at state $6\left({ }^{\circ} \mathrm{K}\right)$.

To calculate the electric power produced, can use the following equation:

$$
W_{t}=M_{w f} \times \eta_{t} \times\left(h_{3}-h_{4 s}\right)
$$

where:

$\mathrm{W}_{\mathrm{t}}=$ The electric power is generated $(\mathrm{kWe})$;

$\mathrm{M}_{\mathrm{wf}}=$ The mass flow rate of the working fluid $(\mathrm{kg} / \mathrm{s})$;

$\mathrm{H}_{\mathrm{t}}=$ Turbine efficiency $(\%)$;

$\mathrm{h}_{3} \&_{4}=$ Enthalpy inlet \& outlet Turbine $(\mathrm{kJ} / \mathrm{kg})$.

\subsection{Efficiency cycles thermal}

To find out the specific performance of the turbine needed, equations can be used [14];

$$
W_{t}=h_{1}-h_{2}
$$

Working specification of Feed pump, the equation can be used:

$$
W_{P}=h_{5}-h_{4}
$$

The heat transfer working fluid, can be used equation:

$$
Q_{\text {in }}=h_{1}-h_{5}
$$

Thermal efficiency is the ratio of the net power generated by the head bed applied to a system. This value shows how much power can be produced with a certain heat input. Thermal efficiency can be calculated using the equation [15]:

$$
\eta_{t h}=\frac{\left(W_{t}-W_{P}\right)}{q_{i n}}
$$

\section{RESULT AND DISCUSSION}

\subsection{Determination of pressure and temperature loss}

Initially, the LHD Unit III Field will only utilize the steam produced. However, seeing the huge potential of brine seen from pressure, temperature, and mass flow, the Unit III LHD Field has the potential to build binary cycle power plant. In accordance with the plan, the LHD-5 and LHD-19 are wells is cluster that the drilled in the same structure, so that they have relatively the same characteristic and production. These two wells are planned for the construction of a small-scale power plant with binary cycle. From the well distributed with one flow line to the manifold, and then this two-phase fluid is flowed with the lager flow line to the separator. Then from the separator, the brine will flow through the brine manifold to the heat exchanger. In the heat exchanger there is heat transfer between the produced brine and the working fluid.

Working fluid which has changed phase into gas will be directly used to rotate the gas turbine. The working fluid that has been used is then condensed in the condenser to return the phase to liquid. This liquid is then pumped back to the heat ex changer to be reheated by the produced brine. This cycle continues. Table 1A, to explain well output data from LHD-5 and LHD-19 Well and Table 1B, as dimension pipe from Manifold and to Separator.

From Table 1A describes the conditions of Pressure, Temperature, Mas Flow, and enthalpy of the LHD-5 and LHD19 Wellheads, where these two wells are drilled in the same structure as the cluster model and to facilitate field operations,

\begin{tabular}{|c|c|c|c|}
\hline & & $\begin{array}{c}\text { LHD- } \\
5\end{array}$ & $\begin{array}{c}\text { LHD- } \\
19\end{array}$ \\
\hline \multirow{3}{*}{$\begin{array}{l}\text { Well to Manifold } \\
\text { Pipeline Dimension }\end{array}$} & $\begin{array}{l}\text { Inside Diameter } \\
\text { (inch) }\end{array}$ & 11.75 & 11.75 \\
\hline & $\begin{array}{c}\text { Outside } \\
\text { Diameter (inch) }\end{array}$ & 12.75 & 12.75 \\
\hline & $\begin{array}{l}\text { Pipe Thickness } \\
\text { (inch) }\end{array}$ & 0.5 & 0.5 \\
\hline \multirow{3}{*}{$\begin{array}{l}\text { Manifold to Separator } \\
\text { Pipeline Dimension }\end{array}$} & $\begin{array}{l}\text { Inside Diameter } \\
\text { (inch) }\end{array}$ & \multicolumn{2}{|c|}{15} \\
\hline & $\begin{array}{c}\text { Outside } \\
\text { Diameter (inch) }\end{array}$ & \multicolumn{2}{|c|}{16} \\
\hline & $\begin{array}{l}\text { Pipe Thickness } \\
\text { (inch) }\end{array}$ & \multicolumn{2}{|c|}{0.5} \\
\hline
\end{tabular}
these two wells are set to the same size of choke, resulting in the same output parameters.

Table 1A. Well output data LHD-5 and LHD-19 Wellheads

\begin{tabular}{ccc}
\hline \multirow{2}{*}{ Well Data } & \multicolumn{2}{c}{ Well Output } \\
\cline { 2 - 3 } & LHD-5 & LHD-9 \\
\hline Fluid & 2 Phase & 2 Phase \\
Temperature $\left({ }^{\circ} \mathrm{C}\right)$ & 193 & 193 \\
Pressure $(\mathrm{bar})$ & 13.34 & 13.34 \\
Mass Flow $(\mathrm{kg} / \mathrm{s})$ & 50.399 & 50.399 \\
Steam Quality $(\%)$ & 20 & 20 \\
Enthalpy $(\mathrm{kJ} / \mathrm{kg})$ & 1214.7 & 1214.7 \\
\hline
\end{tabular}

Table 1B. Dimension pipeline from wellhead-manifold and separator

In this plan, the type used is A106 Grade B type carbon steel, XS (Extra Strong) type because this type can be used in high temperature and high-pressure conditions, making it suitable for geothermal fields. Table 4 is a calculation on each pipe 
segment to determine the pipe schedule according to ASME B36.10M standard and the flow velocity in the pipe.

The pipe segment from the LHD-5 well to the manifold uses a pipe with Di (inner diameter) of 11.75 inch, Do (outer diameter) $12.75 \mathrm{inch}$, and s (pipe thickness) of $0.5 \mathrm{inch}$. The 2-phase fluid rate of steam and brine flowing in this segment is $24.565 \mathrm{~m} / \mathrm{s}$. LHD-19 well to the manifold uses pipes with Di (inner diameter) of 11.75 inch, Do (outer diameter) of 12.75 inch, and s (pipe thickness) of 0.5 inch. The 2-phase fluid rate of steam and brine flowing in this segment is $26.338 \mathrm{~m} / \mathrm{s}$. Pipeline segment pipeline from the manifold to the separator uses pipes with 15 inches, 16 inches, and 0.5 inches. The 2phase fluid rate of steam and brine flowing in this segment is $26.98 \mathrm{~m} / \mathrm{s}$.

Fluid Flow 2 phase from Production Well (LHD-5 and LHD-19) to Manifold and Separator and Single-phase fluid (Brine) from Separator to Head Ex changer. Well output data from each well, LHD-5 and LHD-19 are attached in Table 1. The data will need to be corrected by the pressure and temperature losses that occur along the pipe so that the separator output brine data will be obtained, which will be used for the calculation of this study. The flow from well to separator in the 2-phase pipeline causes pressure and temperature loss which will affect the quality of steam and enthalpy.

The pressure and temperature loss are analyzed using the Pipe-sim simulator. The assumption using proper insulation so that the heat loss does not spread to the pipe surface and only calculates the loss of pressure and temperature along the 2phase pipeline, as shown in Table 2, Table 3. Pressure and temperature loss data in to phase (Liquid dominated system) from Production Well (LHD-5 and LHD-19) to Manifold, can show in Table 2A and Table 2B.

Table 2A. Pressure and temperature loss in two-phase, from LHD-5 and LHD-19 to manifold

\begin{tabular}{ccccccccc}
\hline \multirow{2}{*}{ Well } & \multicolumn{2}{c}{ Wellhead } & \multicolumn{2}{c}{ Loss Through Well-Inlet Valve $\mathbf{A}_{1} / \mathbf{A}_{2}$} & \multicolumn{2}{c}{ Inlet Valve $\mathbf{A}_{1} / \mathbf{A}_{2}$} & \multicolumn{2}{c}{ Loss in Valve $\mathbf{A}_{1} / \mathbf{A}_{2}$} \\
\cline { 2 - 9 } & $\mathrm{P}($ bar $)$ & $\mathrm{T}\left({ }^{\circ} \mathrm{C}\right)$ & $\mathrm{P}($ bar $)$ & $\mathrm{T}\left({ }^{\circ} \mathrm{C}\right)$ & $\mathrm{P}($ bar $)$ & $\mathrm{T}\left({ }^{\circ} \mathrm{C}\right)$ & $\mathrm{P}($ bar $)$ & $\mathrm{T}\left({ }^{\circ} \mathrm{C}\right)$ \\
\hline LHD-5 & 13.4 & 193 & 0.0726 & 0.249 & 13.3274 & 192.75 & 0.000219 & 0 \\
LHD-19 & 13.4 & 193 & 0.0726 & 0.249 & 13.3274 & 192.75 & 0.000219 & 0 \\
\hline
\end{tabular}

Table 2B. Pressure and temperature loss in two-phase, from LHD-5 and LHD-19 to manifold

\begin{tabular}{ccccccc}
\hline \multirow{2}{*}{ Well } & \multicolumn{2}{c}{ Inlet Valve $\mathbf{A}_{1} / \mathbf{A}_{2}$} & \multicolumn{2}{c}{ Loss Through Well-Inlet Valve A1/ $\mathbf{A}_{2}$} & \multicolumn{2}{c}{ Inlet Manifold } \\
\cline { 2 - 7 } & $\mathrm{P}($ bar $)$ & $\mathrm{T}\left({ }^{\circ} \mathrm{C}\right)$ & $\mathrm{P}($ bar $)$ & $\mathrm{T}\left({ }^{\circ} \mathrm{C}\right)$ & $\mathrm{P}(\mathrm{bar})$ & $\mathrm{T}\left({ }^{\circ} \mathrm{C}\right)$ \\
\hline LHD-5 & 13.3272 & 192.75 & 0.216681 & 0.757 & 13.111 & 191.99 \\
LHD-19 & 13.3272 & 192.75 & 0.216681 & 0.757 & 13.111 & 191.99 \\
\hline
\end{tabular}

Table 3A. Pressure and temperature loss in two-phase from manifold to separator

\begin{tabular}{cccccccccc}
\hline \multicolumn{2}{l}{ Outlet Manifold } & \multicolumn{2}{c}{ Loss Through Manifold-Inlet Valve B } & \multicolumn{2}{c}{ Inlet Valve B } & \multicolumn{2}{c}{ Loss in Valve B } & \multicolumn{2}{c}{ Outlet Valve B } \\
\hline $\mathrm{P}($ bar $)$ & $\mathrm{T}\left({ }^{\circ} \mathrm{C}\right)$ & $\mathrm{P}($ bar $)$ & $\mathrm{T}\left({ }^{\circ} \mathrm{C}\right)$ & $\mathrm{P}($ bar $)$ & $\mathrm{T}\left({ }^{\circ} \mathrm{C}\right)$ & $\mathrm{P}($ bar $)$ & $\mathrm{T}\left({ }^{\circ} \mathrm{C}\right)$ & $\mathrm{P}(\mathrm{bar})$ & $\mathrm{T}\left({ }^{\circ} \mathrm{C}\right)$ \\
\hline 13.1 & 191.99 & 0.065 & 0.23 & 13.0453 & 191.765 & 0.000235 & 0.001 & 13.0456 & 191.764 \\
\hline
\end{tabular}

Table 3B. Pressure and temperature loss in two-phase from manifold to separator (B)

\begin{tabular}{ccccccccccc}
\hline $\begin{array}{c}\text { Loss Through Valve B-Inlet } \\
\text { Separator }\end{array}$ & \multicolumn{2}{c}{ Inlet Separator } & \multicolumn{2}{c}{$\begin{array}{c}\text { Loss Inside } \\
\text { Separator }\end{array}$} & \multicolumn{2}{c}{$\begin{array}{c}\text { Outlet } \\
\text { Separator }\end{array}$} & \multicolumn{2}{c}{$\begin{array}{c}\text { Loss Through Outlet Separator- } \\
\text { Inlet Valve C }\end{array}$} \\
\hline $\mathrm{P}(\mathrm{bar})$ & $\mathrm{T}\left({ }^{\circ} \mathrm{C}\right)$ & $\mathrm{P}(\mathrm{bar})$ & $\mathrm{T}\left({ }^{\circ} \mathrm{C}\right)$ & $\mathrm{P}(\mathrm{bar})$ & $\mathrm{T}\left({ }^{\circ} \mathrm{C}\right)$ & $\begin{array}{c}\mathrm{P} \\
(\mathrm{bar})\end{array}$ & $\mathrm{T}\left({ }^{\circ} \mathrm{C}\right)$ & $\mathrm{P}(\mathrm{bar})$ & $\mathrm{T}\left({ }^{\circ} \mathrm{C}\right)$ \\
\hline 1.264665 & 4.64 & 11.7804 & 187.124 & 0.0136 & 0.0136 & 10.3 & 181.166 & 0.0136 & 0.057 \\
\hline
\end{tabular}

Table 4. Pressure and temperature loss in single-phase brain from separator to heat exchanger

\begin{tabular}{|c|c|c|c|c|c|c|c|c|c|c|c|c|c|}
\hline \multicolumn{2}{|c|}{$\begin{array}{c}\text { Outlet } \\
\text { Separator }\end{array}$} & \multicolumn{2}{|c|}{$\begin{array}{l}\text { Loss Through } \\
\text { Outlet Separator- } \\
\text { Inlet Valve C }\end{array}$} & \multicolumn{2}{|c|}{ Inlet Valve C } & \multicolumn{2}{|c|}{$\begin{array}{c}\text { Loss in Valve } \\
\text { C }\end{array}$} & \multicolumn{2}{|c|}{ Outlet Valve C } & \multicolumn{2}{|c|}{$\begin{array}{c}\text { Loss Through } \\
\text { Outlet Valve C- } \\
\text { Inlet HE }\end{array}$} & \multicolumn{2}{|c|}{$\begin{array}{l}\text { Inlet Heat } \\
\text { Exchanger }\end{array}$} \\
\hline $\begin{array}{c}\mathrm{P} \\
\text { (bar) }\end{array}$ & $\mathrm{T}\left({ }^{\circ} \mathrm{C}\right)$ & $\mathrm{P}$ (bar) & $\mathrm{T}\left({ }^{\circ} \mathrm{C}\right)$ & $\mathrm{P}$ (bar) & $\mathrm{T}\left({ }^{\circ} \mathrm{C}\right)$ & $\mathrm{P}$ (bar) & $\begin{array}{c}\mathrm{T} \\
\left({ }^{\circ} \mathrm{C}\right) \\
\end{array}$ & $\mathrm{P}$ (bar) & $\mathrm{T}\left({ }^{\circ} \mathrm{C}\right)$ & $\mathrm{P}$ (bar) & $\mathrm{T}\left({ }^{\circ} \mathrm{C}\right)$ & $\begin{array}{c}\mathrm{P} \\
\text { (bar) }\end{array}$ & $\mathrm{T}\left({ }^{\circ} \mathrm{C}\right)$ \\
\hline 10.3 & 181.166 & 0.0136 & 0.057 & 10.2864 & 181.109 & 0.0005 & 0.002 & 10.2859 & 181.107 & 0.0559 & 0.238 & 10.23 & 180.69 \\
\hline
\end{tabular}

Table 5. Fluid data in each nodal

\begin{tabular}{lccccc}
\hline \multirow{2}{*}{ Well Data } & \multicolumn{2}{c}{ Well Output } & \multirow{2}{*}{ Manifold } & \multirow{2}{*}{ Inlet Separator } & \multirow{2}{*}{ Outlet Separator } \\
& LHD-5 & LHD-9 & & & \\
\hline Fluid & 2 Phase & 2 Phase & 2 Phase & 2 Phase & 1 Phase (Brine) \\
Temperature $\left({ }^{\circ} \mathrm{C}\right)$ & 193 & 193 & 192.97 & 192.896 & 180.8 \\
Pressure $(\mathrm{bar})$ & 13.34 & 13.34 & 13.175 & 11.865 & 10.23 \\
Mass Flow $(\mathrm{kg} / \mathrm{s})$ & 50.399 & 50.399 & 100.798 & 100.798 & 82.05 \\
Steam Quality $(\%)$ & 20 & 20 & 19.75 & 18.6 & 0 \\
Enthalpy $(\mathrm{kJ} / \mathrm{kg})$ & 1214.7 & 1214.7 & 1210.48 & 1187.34 & 766.89 \\
\hline
\end{tabular}


The pressure and temperature loss in two-phase (liquid Dominated) from Manifold to Separator as follow in Table 3A and Table 3B. Evaluation of value pressure dan temperature loss single phase (Brine) from Separator to Head Ex-changer to show in Table 4.

The amount of pressure loss and temperature of fluid flowing from the LHD-5 well to the manifold through a pipe with an outer diameter of 12.75 inches and the length of the pipe is assumed to be $40 \mathrm{~m}$ is 0.29 bar for pressure loss and $0.023^{\circ} \mathrm{C}$ for temperature loss. From the LHD-19 well to the manifold through a pipe with an outer diameter of 12.75 inches and a pipe length assumed to be $40 \mathrm{~m}$ is 0.2 bar for pressure loss and $0.03^{\circ} \mathrm{C}$ for temperature loss. From the manifold to the separator inlet also experiences pressure and temperature loss. Outlet pressure and temperature data used in the manifold are the smallest data between LHD-5 and LHD-19 wells.

Wellhead temperature can will decrease each year because the ability to produce geothermal fluid will also decrease annually. The decrease in wellhead temperature will also affect the decrease in the brine temperature entering the heat ex changer. With the prediction for over 17 years, from 2020 to 2036 and the reduction in wellhead temperature by an average of $3 \%$ / year, the annual temperature reduction can be seen in Figure 2.

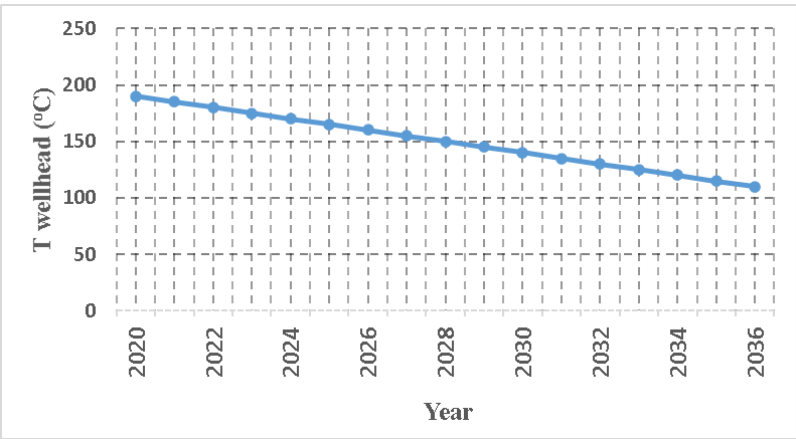

Figure 2. Wellhead temperature decline every year (From 2019-2037)

Thus, tabulation for each fluid data from the LHD-5 and LHD-19 wells on each nodal that has been corrected with pressure and temperature loss, shown in Table 5.

Value of the pressure and temperature of the brine fluid that comes out of the temperature is very dependent on the magnitude of the pressure and temperature of the wellhead, the loss of pressure and temperature along the flow from the well to the Separator and the loss of pressure and temperature when flashing occurs in the Separator. The method uses the Beggs and Brill as method for 2-phase fluids (liquid and vapor) assisted by the Pipesim software, assuming the pipe insulation works perfectly so that no heat comes out of the pipe wall.

The assumptions made in the calculation of pressure loss and temperature loss, there is no expansion of the length of the pipe so that there is no expansion loop or the pipe is considered a horizontal pipe, the fluid velocity in the pipe is assumed to be $40 \mathrm{~m} / \mathrm{second}$. There is no heat coming out of the pipe (Insulation works perfectly) there is no condensate in the flow.

The amount of pressure loss and temperature of the fluid from the manifold to the separator inlet that flows in a 16 inches outer diameter pipe assuming a pipe length of $210 \mathrm{~m}$ is 1.31 bar for pressure loss and $0.08^{\circ} \mathrm{C}$ for temperature loss. Inside the separator also occurs a pressure loss of 1.57 bar and $12.1^{\circ} \mathrm{C}$ for temperature loss. So, the output data for brine separator is temperature of $180.8^{\circ} \mathrm{C}$, pressure of 10.23 bar, mass flow rate of $82.05 \mathrm{~kg} / \mathrm{s}$, enthalpy of $766.89 \mathrm{~kJ} / \mathrm{kg}$, and steam quality of $0 \%$ with the assumption of separation in the separator is perfect.

\subsection{Brine and working fluid in binary cycle}

For more details, the flow of the heating fluid from the Separator to the Heat exchanger and then to the injection well and the flow of the working fluid from this binary cycle can be seen in the following Figure 3.

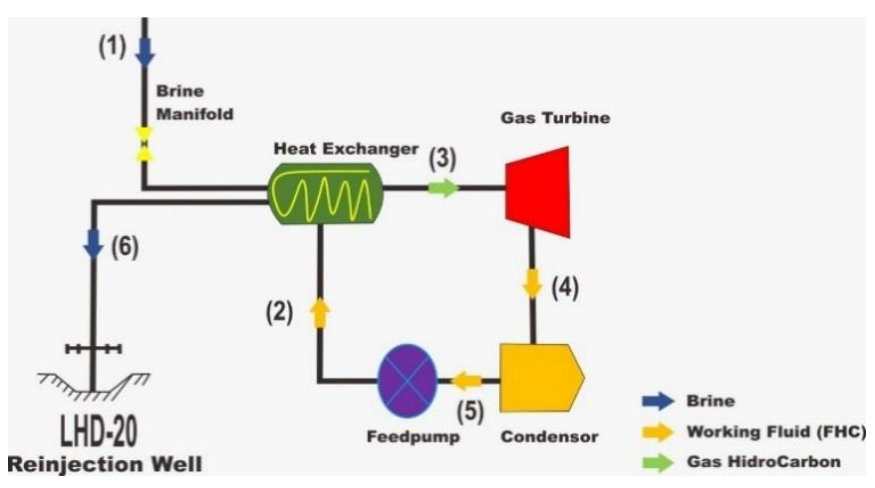

Figure 3. Binary cycle system power plant project

Flow diagram of the heating fluid from the separator to the heat exchanger (1), and from the heat exchanger to the injection well (6). The working fluid from the Feed pump (FP) to the heat ex-changer (2) is heated in the HE, then from the HE to the Turbine (3) drives the Turbine, from the Turbine to the Condenser (4) the working fluid is cooled, then from the Condenser to the Feed pump (5).

The conditions of the working fluid and heating fluid in the binary cycle process can be seen in Table 6 . The pipe planning 1-phase also needs to be done to find out how much the pipe diameter passed by the fluid and the fluid flow velocity in the pipe. This 1-phase pipeline plan includes a separator to heat exchanger segment, a heat ex changer to turbine segment, a turbine to condenser segment, a condenser to feed pump segment, and a feed pump to heat ex changer segment. Pipe Schedule and Fluid Velocity for 1-Phase Pipeline can be seen in the Table 7.

Pipeline from the separator to the heat ex changer has dimensions of 9.75 inch, Do 10.75 inch, and s of 0.5 inch. Brine fluid flow rate of $1.92 \mathrm{~m} / \mathrm{s}$. The pipe segment from the heat exchanger to the turbine has dimensions of 23 inches, 24 inches and 0.5 inches. Working fluid flow rate of $27.67 \mathrm{~m} / \mathrm{s}$.

The pipe segment from the turbine to the condenser has dimensions at 5.762 inches, Do 6.626 inches, and $s$ at 0.432 inches. Flow rate of working fluid flowing at $21,675 \mathrm{~m} / \mathrm{s}$. The pipe segment from the condenser to the feed pump has dimensions at 1.938 inches, Do 2.374 inches, and $\mathrm{s}$ at 0.218 inch. The flow rate of working fluid flowing at $20.353 \mathrm{~m} / \mathrm{s}$.

From the feed pump to the heat ex changer has dimensions of pipe as 1.938 inch, do $2.374 \mathrm{inch}$, and s of 0.218 inch and flow rate of working fluid flowing at $19.70325 \mathrm{~m} / \mathrm{s}$.

\subsection{Working fluid selection a design}

Working fluids from hydrocarbons were used, namely isobutane, iso-pentane, and n-pentane, Working Fluid Characteristic can as shown in Table 8.

The wellhead temperature which decreases every year will 
require changes in the working fluid as well, so that the electrical power produced remains optimum. Table 8 is a characteristic table of several working fluids. In this study only three working fluids from hydrocarbons were used, namely iso-butane, iso-pentane, and n-pentane which are attached in Table 9.

For the iso-butane maximum allowable temperature is $125^{\circ} \mathrm{C}$ and critical temperature is $134.7^{\circ} \mathrm{C}$ as attached in Table 6 . The iso-pentane has maximum allowable temperature of $177^{\circ} \mathrm{C}$ and critical temperature of $187.2^{\circ} \mathrm{C}$. Whereas the n-pentane has a maximum allowable temperature of $186^{\circ} \mathrm{C}$ and a critical temperature of $196.5^{\circ} \mathrm{C}$. The next step is to analyze the thermodynamic cycle. It is important to calculate how much energy is produced.

Table 6. Pipe process and condition fluid

\begin{tabular}{ccccccc}
\hline Pipe Process & $\begin{array}{c}\text { Separator to } \\
\text { HE (1) }\end{array}$ & $\begin{array}{c}\text { Feedpump to } \\
\text { HE (2) }\end{array}$ & $\begin{array}{c}\text { HE to Gas } \\
\text { Turbine (3) }\end{array}$ & $\begin{array}{c}\text { Gas Turbine to } \\
\text { Condenser (4) }\end{array}$ & $\begin{array}{c}\text { Condenser to Feed } \\
\text { pump (5) }\end{array}$ & $\begin{array}{c}\text { HE to Injection } \\
\text { Well (6) }\end{array}$ \\
\hline $\begin{array}{c}\text { Fluid Condition and } \\
\text { Function }\end{array}$ & Heat Fluid & $\begin{array}{c}\text { Working Fluid } \\
\text { (cool) }\end{array}$ & $\begin{array}{c}\text { Heat Working } \\
\text { Fluid }\end{array}$ & $\begin{array}{c}\text { Heat Working Fluid } \\
\text { (Turbine Exhaust) }\end{array}$ & $\begin{array}{c}\text { Cool Working } \\
\text { Fluid }\end{array}$ & Coll Fluid \\
\hline Fluid Type & $\begin{array}{c}\text { Brine (Liquid } \\
\left.\mathrm{H}_{2} \mathrm{O}\right)\end{array}$ & Liquid (HC) & Gas (HC) & Condensate (HC) & $\begin{array}{c}\text { Liquid } \\
(\mathrm{HC})\end{array}$ & $\begin{array}{c}\text { Brine }(\text { Liquid } \\
\left.\mathrm{H}_{2} \mathrm{O}\right)\end{array}$ \\
\hline
\end{tabular}

Table 7. Pipe Schedule and fluid velocity for 1-phase pipeline

\begin{tabular}{cccccc}
\hline Pipe & Separator to HE & HE to Turbine & Turbine to Condenser & Condenser to Feed pump & Feed Pump to HE \\
\hline Di (inch) & 9.75 & 23 & 5.762 & 1.938 & 1.938 \\
Do (inch) & 10.75 & 24 & 6.626 & 2.374 & 0.218 \\
S (inch) & 0.5 & 0.5 & 0.432 & 20.353 & 0.218 \\
Fluid Velocity (m/s) & 1.92 & 27.67 & 21.675 & 19.7 & \\
\hline
\end{tabular}

Table 8. Working fluid characteristic [9]

\begin{tabular}{|c|c|c|c|c|c|c|c|c|}
\hline Fluid & $\begin{array}{c}\text { Formul } \\
\mathbf{a} \\
\end{array}$ & $\begin{array}{c}\text { Critical Temp. } \\
\left({ }^{\circ} \mathrm{C}\right)\end{array}$ & $\begin{array}{l}\text { Critical Pressure } \\
\text { (bar) }\end{array}$ & $\begin{array}{c}\text { Molar mass } \\
(\mathrm{kg} / \mathrm{mol})\end{array}$ & Toxicity & $\begin{array}{c}\text { Flammabilit } \\
\mathbf{y}\end{array}$ & $\begin{array}{c}\text { ODP } \\
+ \\
\end{array}$ & $\begin{array}{c}\text { GWP }^{+} \\
+ \\
\end{array}$ \\
\hline Propane & $\mathrm{C}_{3} \mathrm{H}_{3}$ & 96.95 & 42.36 & 44.09 & Low & very high & 0 & 3 \\
\hline i-Butane & $\mathrm{C}_{4} \mathrm{H}_{10}$ & 135.9 & 36.85 & 58.12 & Low & very high & 0 & 3 \\
\hline n-Butane & $\mathrm{C}_{4} \mathrm{H}_{0}$ & 150.8 & 37.18 & 58.12 & Low & very high & 0 & 3 \\
\hline $\begin{array}{c}\text { i- } \\
\text { Pentane }\end{array}$ & $\mathrm{C}_{5} \mathrm{H}_{12}$ & 187.8 & 34.09 & 72.15 & Low & very high & 0 & 3 \\
\hline $\begin{array}{c}\mathrm{n}- \\
\text { Pentane }\end{array}$ & $\mathrm{C}_{4} \mathrm{H}_{12}$ & 193.9 & 32.40 & 72.15 & Low & very high & 0 & 3 \\
\hline $\mathrm{R}-12$ & $\mathrm{CCl}_{2} \mathrm{~F}_{2}$ & 112.0 & 41.14 & 120.9 & $\begin{array}{l}\text { non- } \\
\text { toxic }\end{array}$ & non-flam & 1.0 & 4,500 \\
\hline $\mathrm{R}-114$ & $\mathrm{C}_{2} \mathrm{Cl}_{2} \mathrm{~F}_{4}$ & 145.7 & 32.89 & 170.9 & $\begin{array}{l}\text { non- } \\
\text { toxic }\end{array}$ & non-flam & 0.7 & 5,850 \\
\hline $\mathrm{R}-134 \mathrm{a}$ & $\begin{array}{c}\mathrm{CH}_{2} \mathrm{FCF} \\
3\end{array}$ & 101.0 & 40.59 & 102.0 & Low & non-flam & 0 & 1,430 \\
\hline $\mathrm{R}-254 \mathrm{fa}$ & $\mathrm{C}_{3} \mathrm{H}_{3} \mathrm{~F}_{3}$ & 154.0 & 36.51 & 134.0 & Low & non-flam & 0 & 1,030 \\
\hline $\begin{array}{l}\text { Ammoni } \\
\text { a }\end{array}$ & $\mathrm{NH}_{3}$ & 133.6 & 116.27 & 17.03 & Toxic & Lower & 0 & 0 \\
\hline Water & $\mathrm{H}_{2} \mathrm{O}$ & 374.1 & 220.89 & 18.02 & $\begin{array}{l}\text { non- } \\
\text { toxic }\end{array}$ & non-flam & 0 & - \\
\hline
\end{tabular}

Table 9. Chosen working fluid properties

\begin{tabular}{ccccccc}
\hline Working Fluid & Boiling Point, $\left({ }^{\circ} \mathbf{C}\right)$ & P.Cond, $($ bar $)$ & T.Max, $\left({ }^{\circ} \mathbf{C}\right)$ & P.Max, $($ bar $)$ & T.C, $\left({ }^{\circ} \mathbf{C}\right)$ & P.C, $($ bar $)$ \\
\hline Iso-butane & -11.7 & 5.03 & 125 & 28.9 & 134.7 & 3.505 \\
Iso-pentane & 27.8 & 1.45 & 177 & 28.87 & 187.2 & 0.918 \\
n-pentane & 36.1 & 1.1 & 186 & 28.65 & 196.5 & 0.683 \\
\hline
\end{tabular}

\subsection{Thermodynamic state of fluid working HC}

Thermodynamic state from Working fluid is condition Pressure, Temperature Enthalpy and Entropy in binary cycle process. In this state, the working fluid the process moves from one equipment to another with different conditions of pressure, temperature, and enthalpy. This situation is described in 8 working conditions. State $2 \mathrm{~s}$ is a state where the pressure state is the same as condition 3, which is $0.53 \mathrm{MPa}$, but has a different temperature, where for the $\mathrm{T} 3$ temperature it must reach vapor saturated, so it has a different enthalpy from the $2 \mathrm{~s}$ state. Of particular significance for the $2 \mathrm{~S}$ state is the state of peak enthalpy but the fluid has not yet reached vapor saturation.

The are 8 states of the working fluid in this binary cycle, namely: State 1 (Turbine), State 2 (Turbine output), State $2 \mathrm{~s}$ (isotropic condition at Turbine outlet), State 2 (Turbine outlet conditions), State 3, State 4 (feed pump), state 5, state 5 s and state 6 .

State 1: Vapour Saturated, at $\mathrm{P}_{(1)}=2 \mathrm{MPa}$

$\mathrm{s} 1=2.0735 \mathrm{~kJ} / \mathrm{kg}{ }^{\circ} \mathrm{K}$

$\mathrm{h} 1=642.378 \mathrm{~kJ} / \mathrm{kg}$

State 2: Use Equation Turbine Efficiency, $\mathrm{P}_{(2)}=0.53 \mathrm{MPa}$

$\mathrm{h} 2=\mathrm{h} 1-\eta \mathrm{t}(\mathrm{h} 1-\mathrm{h} 2)=582.875 \mathrm{~kJ} / \mathrm{kg}$ 
State 2s: Isotrophic Condition With state 1

$\mathrm{S}\left({ }_{2} \mathrm{~S}\right)=\mathrm{s} 1 ; \mathrm{P}\left({ }_{2} \mathrm{~S}\right)=$ Pcond.

Interpolation $\mathrm{s}$ at $\mathrm{T}=372.5^{\circ} \mathrm{K}$

$\mathrm{S}=2.0735 \mathrm{~kJ} / \mathrm{kg}, \mathrm{h} 2 \mathrm{~s}=591.8 \mathrm{~kJ} / \mathrm{kg}$

State 3: Vapour Saturated, at $\mathrm{P}_{(3)}=0.53 \mathrm{MPa}$

$\mathrm{h} 3=567.081 \mathrm{~kJ} / \mathrm{kg}$

State 4: Liquid Saturation, at $\mathrm{P}_{(4)}=0.53 \mathrm{MPa}$

$\mathrm{h} 4=249.59 \mathrm{~kJ} / \mathrm{kg}$

$\mathrm{v} 4=0.001858 \mathrm{~m}^{3} / \mathrm{kg}$

used v4, because is approach enthalpy for state $5 \mathrm{~s}$

State 5: Efficiency pump equal with Turbine,

However numerator Isentropic condition

and denominatory is actual working.

$\mathrm{P}=2 \mathrm{MPa}, \mathrm{T}=310.7^{\circ} \mathrm{K}$

$=249.539 \mathrm{~kJ} / \mathrm{kg}$

State $5 \mathrm{~s}$ : Isentropic pump outlet state;

$\mathrm{P} 5 \mathrm{~s}=2 \mathrm{MPa}$, Because liquid almost in compressible condition,

$\mathrm{h} 5 \mathrm{~s}$ can be determined. h5s $\approx \mathrm{h} 4+\mathrm{v} 4(\mathrm{P} 5 \mathrm{~s}-\mathrm{P} 4)$

$=249.594 \mathrm{~kJ} / \mathrm{kg}$

State 6: Liquid Saturation at P6 $=2 \mathrm{MPa}$

$\mathrm{T} 6=372.585^{\circ} \mathrm{K}$

$\mathrm{h} 6=427.816 \mathrm{~kJ} / \mathrm{kg}$.

Thermodynamics State of working fluid iso-butane is described on Table 10.

Table 10. Thermodynamic state of iso-butane

\begin{tabular}{cccccc}
\hline State & $\begin{array}{c}\mathbf{P} \\
(\mathbf{M p a})\end{array}$ & $\mathbf{T}\left({ }^{\mathbf{0}} \mathbf{K}\right)$ & $\begin{array}{c}\mathbf{S . V} \\
\left(\mathbf{m}^{\mathbf{3}} / \mathbf{k g}\right)\end{array}$ & $\begin{array}{c}\mathbf{S} \\
(\mathbf{k J} / \mathbf{k g})\end{array}$ & $\begin{array}{c}\mathbf{H} \\
(\mathbf{k J} / \mathbf{k g})\end{array}$ \\
\hline 1 & 2 & 372.585 & & 2.0735 & 642.378 \\
2 & 0.503 & & & & 591.8 \\
$2 \mathrm{~s}$ & 0.503 & & & 2.0735 & 582.75 \\
3 & 0.503 & & & & 567.081 \\
4 & 0.503 & & 0.001858 & & 249.59 \\
5 & 2 & 310.7 & & & 249.593 \\
$5 \mathrm{~s}$ & 2 & & & & 249.594 \\
6 & 2 & 372.585 & & & 427.816 \\
\hline
\end{tabular}

The thermodynamic state analysis for iso-butane is shown in Table 10. State 1 is working fluid entering turbine with no fluid droplets with a pressure of $2 \mathrm{Mpa}$ and an enthalpy of $642.378 \mathrm{~kJ} / \mathrm{kg}$. State 2 is the actual state of the turbine output with a pressure of $0.503 \mathrm{MPa}$ and enthalpy of $591.8 \mathrm{~kJ} / \mathrm{kg}$. Whereas state $2 \mathrm{~s}$ is the isotropic state of turbine output with pressure of $0.503 \mathrm{Mpa}$ and enthalpy $582.875 \mathrm{~kJ} / \mathrm{kg}$. In state 3, the working fluid pressure is $0.503 \mathrm{Mpa}$ and enthalpy 567.081 $\mathrm{kJ} / \mathrm{kg}$. The working fluid then enters the feed pump as seen in state 4 with a pressure of $0.503 \mathrm{Mpa}$ and enthalpy of 249.59 $\mathrm{kJ} / \mathrm{kg}$. At state $5 \mathrm{~s}$, the fluid has pressure of $2 \mathrm{Mpa}$ and enthalpy of $249.593 \mathrm{~kJ} / \mathrm{kg}$. In state 5, the actual state of the feed pump and working fluid output enters the heat ex changer with pressure of $2 \mathrm{Mpa}$ and enthalpy of $249.594 \mathrm{~kJ} / \mathrm{kg}$. State 6 shows that the working fluid is still in the saturated liquid with a pressure of $2 \mathrm{MPa}$ and enthalpy of $427.816 \mathrm{~kJ} / \mathrm{kg}$.

The steam returns to the turbine in state 1 . This cycle continues to occur at the binary cycle power plan. Thermodynamics State of iso-pentane can follow at Table 11.

The thermodynamic state analysis for iso-pentane is shown in From Table 11. State 1 is working fluid entering turbine with no fluid droplets with a pressure of $2 \mathrm{Mpa}$ and an enthalpy of $740.75 \mathrm{~kJ} / \mathrm{kg}$. State 2 is the actual state of the turbine output with a pressure of $0.145 \mathrm{MPa}$ and enthalpy of $654.21 \mathrm{~kJ} / \mathrm{kg}$. whereas state $2 \mathrm{~s}$ is the isotropic state of turbine output with pressure of $0.145 \mathrm{Mpa}$ and enthalpy $638.94 \mathrm{~kJ} / \mathrm{kg} \mathrm{K}$. In state 3 , the working fluid pressure is $0.145 \mathrm{Mpa}$ and enthalpy $565.28 \mathrm{~kJ} / \mathrm{kg}$. State 4, working fluid enters the feed pump with pressure of $0.145 \mathrm{Mpa}$ and enthalpy of $229.74 \mathrm{~kJ} / \mathrm{kg}$. At state $5 \mathrm{~s}$, the fluid has pressure of $2 \mathrm{Mpa}$ and enthalpy of 229.743 $\mathrm{kJ} / \mathrm{kg}$. In state 5 , working fluid enters the heat exchanger with pressure of $2 \mathrm{Mpa}$ and enthalpy of $229.744 \mathrm{~kJ} / \mathrm{kg}$. State 6 working fluid is still in the saturated liquid with a pressure of $2 \mathrm{MPa}$ and enthalpy of $545.342 \mathrm{~kJ} / \mathrm{kg}$. Then the steam returns to the turbine in state 1 . This cycle continues to occur at the binary cycle power plant. Thermodynamic state analysis for npentane is shown in Table 12. The thermodynamic state analysis for n-pentane is shown in Table 12 . State 1 is working fluid entering turbine with a pressure of $2 \mathrm{Mpa}$ and an enthalpy of $689.935 \mathrm{~kJ} / \mathrm{kg}$. State 2 is the actual state of the turbine output with a pressure of $0.11 \mathrm{MPa}$ and enthalpy of 592.413 $\mathrm{kJ} / \mathrm{kg}$.

Table 11. Thermodynamics state of iso-pentane

\begin{tabular}{cccccc}
\hline State & $\begin{array}{c}\mathrm{P} \\
(\mathrm{Mpa})\end{array}$ & $\mathrm{T}\left({ }^{\circ} \mathrm{K}\right)$ & $\begin{array}{c}\text { S.Volume } \\
\left(\mathrm{m}^{3} / \mathrm{kg}\right)\end{array}$ & $\begin{array}{c}\text { Entropi } \\
(\mathrm{kJ} / \mathrm{kg})\end{array}$ & $\begin{array}{c}\text { Enthalpy } \\
(\mathrm{kJ} / \mathrm{kg})\end{array}$ \\
\hline 1 & 2 & 436.98 & & 2.2 & 740.75 \\
2 & 0.145 & & & & 654.21 \\
$2 \mathrm{~s}$ & 0.145 & & & 2.2 & 638.94 \\
3 & 0.145 & & & & 565.28 \\
4 & 0.145 & & 0.001662 & & 229.74 \\
5 & 2 & 311.68 & & & 229.744 \\
$5 \mathrm{~s}$ & 2 & & & & 229.743 \\
6 & 2 & 426.98 & & & 545.342 \\
\hline
\end{tabular}

Table 12. Thermodynamic state of n- Pentana

\begin{tabular}{cccccc}
\hline State & $\begin{array}{c}\mathrm{P} \\
(\mathrm{Mpa})\end{array}$ & $\mathrm{T}\left({ }^{\mathrm{o}} \mathrm{K}\right)$ & $\begin{array}{c}\text { S.Volume } \\
\left(\mathrm{m}^{3} / \mathrm{kg}\right)\end{array}$ & $\begin{array}{c}\text { Entropi } \\
(\mathrm{kJ} / \mathrm{kg})\end{array}$ & $\begin{array}{c}\text { Enthalpy } \\
(\mathrm{kJ} / \mathrm{kg})\end{array}$ \\
\hline 1 & 2 & 436.24 & & 1.89 & 689.935 \\
2 & 0.11 & & & & 592.413 \\
$2 \mathrm{~s}$ & 0.11 & & & 1.89 & 575.22 \\
3 & 0.11 & & & & 499.353 \\
4 & 0.11 & & 0.001655 & & 145.923 \\
5 & 2 & 311.32 & & & 145.927 \\
$5 \mathrm{~s}$ & 2 & & & & 145.9265 \\
6 & 2 & 436.24 & & & 489.245 \\
\hline
\end{tabular}

whereas, state $2 \mathrm{~s}$ is the isentropic state of turbine output with pressure of $0.11 \mathrm{Mpa}$ and enthalpy $575.22 \mathrm{~kJ} / \mathrm{kg} \mathrm{K}$. In state 3 , the working fluid pressure is $0.11 \mathrm{Mpa}$ and enthalpy $499.353 \mathrm{~kJ} / \mathrm{kg}$. State 4 working fluid then enters the feed with a pressure of $0.11 \mathrm{Mpa}$ and enthalpy of $145.923 \mathrm{~kJ} / \mathrm{kg}$. At state $5 \mathrm{~s}$, the fluid has pressure of $2 \mathrm{Mpa}$ and enthalpy of 145.9265 $\mathrm{kJ} / \mathrm{kg}$. In state 5 , working fluid enters heat exchanger with pressure of $2 \mathrm{Mpa}$ and enthalpy of $145.927 \mathrm{~kJ} / \mathrm{kg}$. State 6 shows that the working fluid is still in the saturated liquid with a pressure of $2 \mathrm{MPa}$ and enthalpy of $489.245 \mathrm{~kJ} / \mathrm{kg}$. Then the steam returns to the turbine in state 1 . This cycle continues to occur at the binary cycle power plant.

\subsection{Binary cycle power plant design optimization}

Next is calculating the amount of electricity produced by each of these working fluids. This research will predict the planning of a binary cycle power plant for 17 years from 2020 to 2036. Each working fluid will be calculated for how much energy is produced without considering the critical temperature of the working fluid.

The prediction of electrical power is also carried out until the working fluid does not produce electricity anymore. The 
amount of electrical power generated for each wellhead temperature is attached in Table 13.

The n-pentane can be used in the brine temperature range of $180.8^{\circ} \mathrm{C}$ to $169.4^{\circ} \mathrm{C}$. Below the temperature of $169.4^{\circ} \mathrm{C}$, it is not optimum because n-pentane will not produce electricity. The iso-pentane can be used in the brine temperature range of $163.95^{\circ} \mathrm{C}$ to $180.8^{\circ} \mathrm{C}$. Below the temperature of $163.95^{\circ} \mathrm{C}$, it is not optimum because the iso-pentane will not produce electricity. Whereas isobutane can generate electricity from a brine temperature of $106.35^{\circ} \mathrm{C}$ to $180.8^{\circ} \mathrm{C}$. But below $106.35^{\circ} \mathrm{C}$, isobutane can no longer produce electricity. In Figure 4, it can be seen that there is a decrease in the 2-phase fluid temperature at the wellhead and also the brine temperature at the outlet pressures every year by $3^{\circ} \mathrm{C}$ per year.

Table 13. Electric power generation by each working fluid without considering Tc

\begin{tabular}{|c|c|c|c|c|c|c|}
\hline \multirow{2}{*}{ Year } & \multirow{2}{*}{ Year } & \multirow{2}{*}{ Wellhead Temperature $\left({ }^{\circ} \mathrm{C}\right)$} & \multirow{2}{*}{ Inlet Exchanger (Brine) Temperature $\left({ }^{\circ} \mathrm{C}\right)$} & \multicolumn{3}{|c|}{ Electric Power Generated (Mwh) } \\
\hline & & & & iso-butane & iso-pentane & n-pentane \\
\hline 1 & 2020 & 193 & 180.8 & 5.5 & 3 & 1.9 \\
\hline 2 & 2021 & 187 & 175 & 5.1 & 2.2 & 1 \\
\hline 3 & 2022 & 182 & 169.4 & 4.7 & 1.4 & 0.2 \\
\hline 4 & 2023 & 176 & 164 & 4.3 & 0.7 & - \\
\hline 5 & 2024 & 171 & 159 & 4 & - & - \\
\hline 6 & 2025 & 166 & 153.5 & 3.6 & - & - \\
\hline 7 & 2026 & 161 & 148.6 & 3.2 & - & - \\
\hline 8 & 2027 & 156 & 143.7 & 2.8 & - & - \\
\hline 9 & 2028 & 151 & 139 & 2.5 & - & - \\
\hline 10 & 2029 & 147 & 134.5 & 2.2 & - & - \\
\hline 11 & 2030 & 142 & 130 & 1.9 & - & - \\
\hline 12 & 2031 & 138 & 126 & 1.5 & - & - \\
\hline 13 & 2032 & 134 & 121.7 & 1.2 & - & - \\
\hline 14 & 2033 & 130 & 117.7 & 0.9 & - & - \\
\hline 15 & 2034 & 126 & 113.8 & 0.7 & - & - \\
\hline 16 & 2035 & 122 & 110 & 0.4 & - & - \\
\hline 17 & 2036 & 119 & 106 & 0.1 & - & - \\
\hline
\end{tabular}

Table 14. Optimum working fluid vs wellhead temperature

\begin{tabular}{cccccc}
\hline Year & Year & Wellhead T $(\leq)$ & Inlet HE $\left(\right.$ Brine) $\mathbf{T}\left({ }^{\circ} \mathbf{C}\right)$ & Working Fluid & Electric Power $(\mathbf{M w h})$ \\
\hline 1 & 2020 & 193 & 180.8 & n-Pentane & 1.9 \\
\hline 2 & 2021 & 187 & 175 & & 2.2 \\
3 & 2022 & 182 & 169.4 & Iso-Pentane & 1.4 \\
4 & 2023 & 176 & 164 & & 0.7 \\
\hline 5 & 2024 & 171 & 159 & & 4 \\
6 & 2025 & 166 & 153.5 & & 3.6 \\
7 & 2026 & 161 & 148.6 & & 2.2 \\
8 & 2027 & 156 & 143.7 & & 2.5 \\
9 & 2028 & 151 & 139 & & 2.2 \\
10 & 2029 & 147 & 134.5 & & 1.9 \\
11 & 2030 & 142 & 130 & & 1.5 \\
12 & 2031 & 138 & 126 & & 1.2 \\
13 & 2032 & 134 & 121.7 & & 0.9 \\
14 & 2033 & 130 & 117.7 & & 0.7 \\
15 & 2034 & 126 & 113.8 & & 0.4 \\
16 & 2035 & 122 & 110 & & 0.1 \\
17 & 2036 & 119 & 106 & & \\
\hline
\end{tabular}

Figure 4 shows the temperature at which a working fluid is used and produces the amount of electrical power.

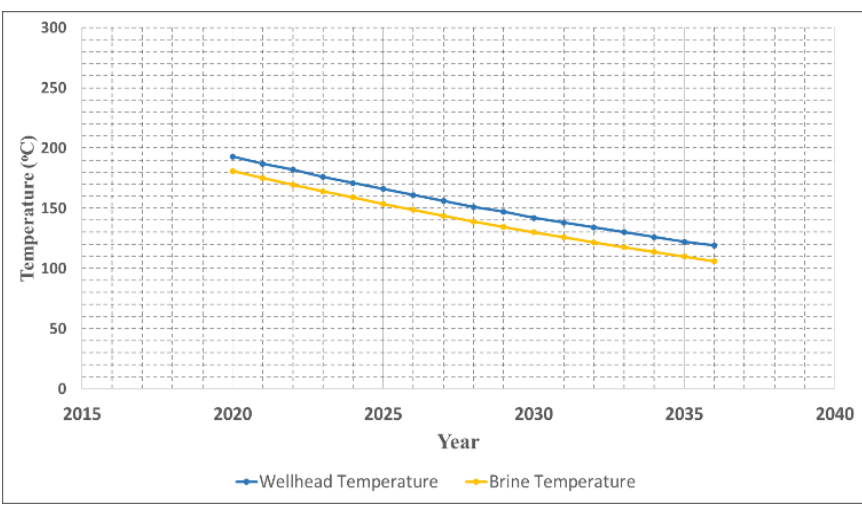

Figure 4. Wellhead and brine temperature drop vs year
In Figure 4, it can be seen that there is a decrease in the 2phase fluid temperature at the wellhead and also the brine temperature at the outlet separator every year by $3^{\circ} \mathrm{C}$ per year.

The n-pentane can be used in the brine temperature range of $180.8^{\circ} \mathrm{C}$ to $169.4^{\circ} \mathrm{C}$. Below the temperature of $169.4^{\circ} \mathrm{C}$, it is not optimum because n-pentane will not produce electricity. The iso-pentane can be used in the brine temperature range of $163.95^{\circ} \mathrm{C}$ to $180.8^{\circ} \mathrm{C}$. Below the temperature of $163.95^{\circ} \mathrm{C}$, it is not optimum because the iso-pentane will not produce electricity. Whereas isobutane can generate electricity from a brine temperature of $106.35^{\circ} \mathrm{C}$ to $180.8^{\circ} \mathrm{C}$, but below $106.35^{\circ} \mathrm{C}$, isobutane can no longer produce electricity.

Figure 5 shows a decrease in wellhead temperature and also the brine temperature at the outlet separator every year by $3^{\circ} \mathrm{C}$ per year. Figure 5 shows the temperature at which a working fluid is used and produces the amount of electrical power. The condition of show each wellhead temperature, iso-butane 
produces the highest electricity, thus can be used at any temperature, but it will not optimal in a cycle. For this reason, it is necessary to on seeder the working fluid maximum allowed temperature and critical temperature.

Well output fluid data needs to be corrected by pressure and temperature loss of the fluid flowing in the pipe. The amount of total pressure loss from the manifold to the separator outlet is $3.17 \mathrm{bar}$ and the total temperature loss is $12.2^{\circ} \mathrm{C}$. Figure 5 . shows a decrease in wellhead temperature and brine temperature each year. Optimum working fluid selection is based on the characteristics of working fluid. Heating fluid (brine) temperature must be bigger than working fluid temperature.

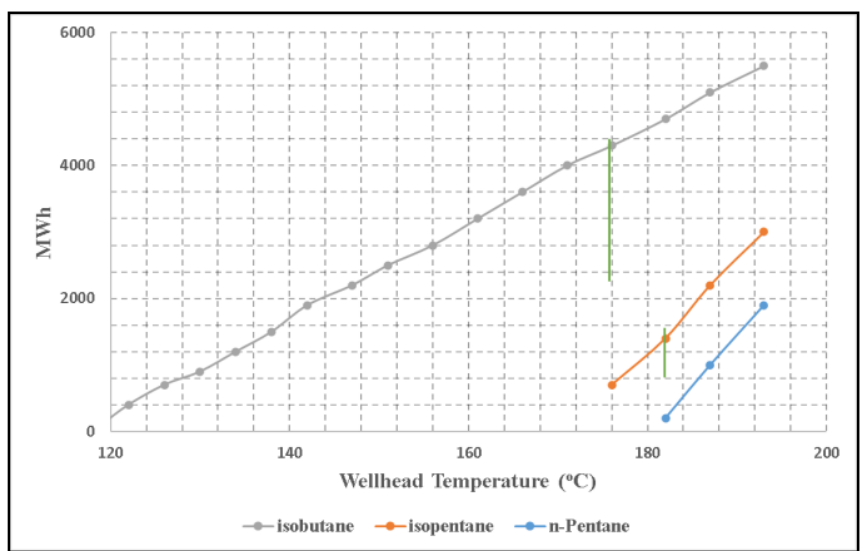

Figure 5. Electric power generated by each working fluid

Each working fluid has the maximum allowable temperature. Other conditions it is also found under a certain temperature, the working fluid does not produce electrical power. Table 14, is shows the optimum working fluid for use at each wellhead temperature.

From Table 14, the optimum n-pentane was used in 1st year with a wellhead temperature of $193^{\circ} \mathrm{C}$, an inlet heat ex changer (brine) temperature of $180.8^{\circ} \mathrm{C}$, and an electric power of 1.9 MWh. Meanwhile the optimum of Iso-pentane is used in 2nd to 4 th years with a wellhead temperature of $176^{\circ} \mathrm{C}-187^{\circ} \mathrm{C}$, an inlet heat exchanger (brine) temperature of $164^{\circ} \mathrm{C}-175^{\circ} \mathrm{C}$, and produces electric power of 0.7-2.2 $\mathrm{MWh}$. Whereas the optimum isobutane is used in the 5 th to 17 th years with a wellhead temperature of $119^{\circ} \mathrm{C}-171^{\circ} \mathrm{C}$, an inlet heat ex changer temperature (brine) of $106^{\circ} \mathrm{C}-159^{\circ} \mathrm{C}$ and the electrical power produced by $0.1-4 \mathrm{MWh}$.

The Figure 6 as show condition of Wellhead temperature sensitivity for each $\mathrm{H}-\mathrm{C}$ working fluid.

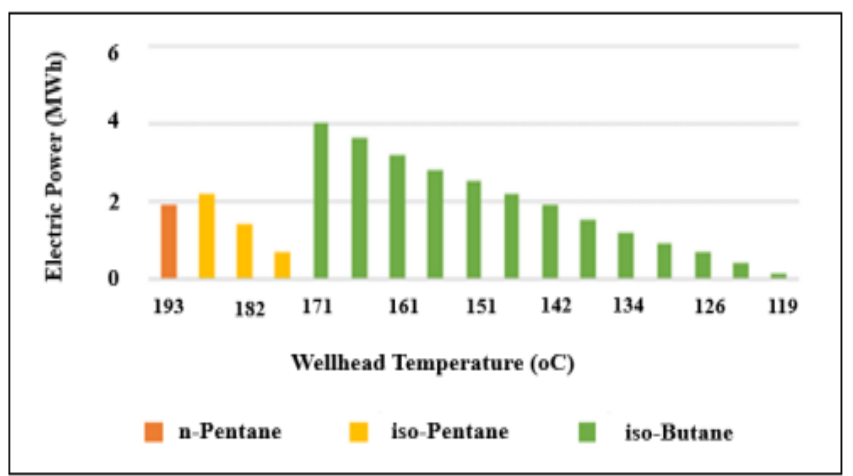

Figure 6. Wellhead temperature sensitivity for each working fluid

\section{CONCLUSIONS}

So far, the brine water from the separator is only discharged into the environment and can damage the environment due to high temperatures. In this study, an analysis of three types of working fluid used to reheat the brine water was analyzed with the following results. From the predictions for 17 years starting from 2020 to 2036 , it was found that the optimum npentane is used in 1st year with a wellhead temperature of $193^{\circ} \mathrm{C}$ and generates electricity of $1.9 \mathrm{MWh}$. The optimum iso-pentane is used in 2nd to 4th years with a wellhead temperature of $176-187^{\circ} \mathrm{C}$ and an electricity of $0.7-2.2 \mathrm{MWh}$, and the optimum isobutane is used in the 5 th to 17 th years with a wellhead temperature of $119-171^{\circ} \mathrm{C}$ and the electricity produced by 0.1- $4 \mathrm{MWh}$. We can maintain the environment by converting existing energy from brine fluid in separator and it will be used to full fill energy need.

\section{ACKNOWLEDGMENT}

The authors would like to thank PERTAMINA Geothermal Company for the field data, also to the UPN Veteran Yogyakarta Geothermal Research Team.

\section{REFERENCES}

[1] Naccarato, F., Potenza, M., De Risi, A., Stigliano, G. (2014). Numerical optimization of an organic Rankine cycle scheme for cogeneration. Int. J. Renew. Energy Res., 4(2): 508-518. https://doi.org/10.20508/ijrer.55498

[2] Cho, S.Y., Jung, Y.B., Cho, C.H. (2018). Experimental study on the organic Rankine cycle for recovering waste thermal energy. Int. J. Renew. Energy Res., 8(1): 120128. https://doi.org/10.1016/j.enconman.2020.113818

[3] Zeyghami, M., Nouraliee, J. (2015). Effect of different binary working fluids on performance of combined flash binary cycle. Preceding World Geothermal Congress, pp. 19-25.

[4] Youssef, E., Dennoun, S. (2018). Preliminary assessment of an organic Rankine cycle power plant derived by linear Fresnel reflector. Int. J. Renew. Energy Res., 8(4): 2014-2024.

[5] Bahrami, M., Hamidi, A.A., Porkhial, S. (2013). Investigation of the effect of organic working fluids on thermodynamic performance of combined cycle Stirling ORC. Int. J. Energy Environment Engineering, 4(1): 1-9. https://doi.org/10.1186/2251-6832-4-12

[6] Escalante, E.S.R., de Carvalho Junior, J.A., Balestieri, J.A.P. (2017). Effect of working fluids on organic Rankine cycle for the recovery of low-grade waste heat. 12th Latin American Congress Electr. Gener. Transm., pp. 1-6. https://doi.org/10.1016/j.energy.2004.01.004

[7] Oreijah, M., Date, As., Date, A., Bryson, M., Akbarzadeh, A. (2012). Expander modelling in binary cycle utilizing geothermal resources for generating green energy in Victoria, Australia. Proceeding Engineering, 49: 316323. https://doi.org/10.1016/j.proeng.2012.10.143

[8] Kohler, S., Saadat, A. (2003). Thermodynamic modeling of binary cycles looking for best case scenario. International Geothermal Conference, Reykjavik, Sept. 2003, 1-14.

[9] Frick, S., Kranz, S., Kupfermann, G., Saadat, A., Huenges, E. (2019). Making use of geothermal power 
brine in Indonesia: Binary demonstration power plant Lahendong (Pangolombian). Geothermal Energy, 7: 30. https://doi.org/10.1186/s40517-019-0147-2

[10] Kurniawan, P., Teguh, B. (2015). Design of $n$ butane radial inflow turbine for $100 \mathrm{~kW}$ binary cycle power plant. International Journal of Engineering \& Technology IJET-IJENS, 11(6): 42-46.

[11] Jiménez, H.M.A., de los Santos, G.L., Torreblanca, M.A.B. (2016). Comparison of the energetic performance of binary cycle and a flash evaporation binary cycle, using low enthalpy geothermal energy. International Journal of Sustainable Engineering, 10(2): 90-98. https://doi.org/10.1080/19397038.2016.1235625

[12] Dagdas, A., Akkoyunlu, M.T., Başaran, T. (2014). Performance analysis of supercritical binary geothermal power plants. Hindawi Publishing Corporation, 7(1):
326839-326839. https://doi.org/10.1155/2014/326839

[13] Dippipo, R. (2007). Geothermal power plants principles, applications, case studies and environmental impact. Second Edition, pp. 11-13; 57-58. https://doi.org/10.1016/B978-0-7506-8620-4.X5001-1

[14] Zhang, F.Z., Jiang, P.X. (2012). Thermodynamic analysis of a binary power cycle for different EGS geofluid temperatures. Applied Thermal Engineering, 48: 476-485. https://doi.org/10.1016/j.applthermaleng.2012.04.028.

[15] Rachmat, A., Nasruddin, Wibowo, A.S., Surachman, A. (2017). Exergoeconomic analysis and optimization of a combined double flash binary cycle for Ulubelu geothermal power plant in Indonesia. 2nd International Tropical Renewable Energy Conference (i-TREC). https://doi.org/10.1088/1755-1315/105/1/012087 